\title{
Size-differential regimes of phytoplankton production in the Northeast Water Polynya $\left(77^{\circ}-81^{\circ} \mathrm{N}\right)$
}

\author{
Stéphane Pesant ${ }^{1, *}$, Louis Legendre ${ }^{1}$, Michel Gosselin ${ }^{2}$, Ralph E. H. Smith ${ }^{3}$, \\ Gerhard Kattner ${ }^{4}$, René O. Ramseier ${ }^{5}$ \\ ${ }^{1}$ GIROQ, Département de biologie, Université Laval, Ste-Foy, Québec, Canada G1K 7P4 \\ ${ }^{2}$ Département d'océanographie, Université du Québec à Rimouski, 310 Allée des Ursulines, Rimouski, Québec, Canada G5L 3A1 \\ ${ }^{3}$ Department of Biology, University of Waterloo, Waterloo, Ontario, Canada N2L 3G1 \\ ${ }^{4}$ Alfred-Wegener-Institut für Polar- und Meeresforschung, Postfach 120161, D-27515 Bremerhaven, Germany \\ ${ }^{5}$ Microwave Group-Ottawa River Inc., 3954 Armitage Ave. RR\#1, Dunrobin, Ontario, Canada K0A 1T0
}

\begin{abstract}
Environmental control and potential fate of phytoplankton production were investigated in the Northeast Water Polynya $\left(77^{\circ}\right.$ to $\left.81^{\circ} \mathrm{N}\right)$, from 23 May to 31 July 1993 . Sampling covered a mosaic of conditions ranging from open to fully ice-covered waters. Three regimes of phytoplankton production are identified, on the basis of the contribution of phytoplankton size fractions ( $>5 \mu \mathrm{m}$ and $<5 \mu \mathrm{m}$ ) to total pigment biomass and production: (1) One regime corresponded to heavily ice-covered $(>50 \%)$ areas and was characterized by biomass and production dominated by small phytoplankton. The 2 other production regimes were found in open waters and/or mixed ice conditions. (2) In one case, surface stratification was strong, nutrients were abundant, biomass and production were dominated by large phytoplankton, and maximum chlorophyll a (chl a) was located near the surface. (3) In the other regime, the surface layer was strongly influenced by melt water, the pycnocline was relatively deep $(>10 \mathrm{~m})$, the biomass was dominated by large phytoplankton, production was shared by small and large phytoplankton, and maximum chl a was associated with the pycnocline. The dominant taxa in the 3 production regimes were flagellates, pennate diatoms and centric diatoms, respectively. The different primary production regimes reflect different export characteristics and could correspond to different pelagic food webs.
\end{abstract}

KEY WORDS: Phytoplankton production regimes S Size fractions - Exportation Food webs Northeast Water Polynya

\section{INTRODUCTION}

In the context of possible global warming, an increasing proportion of marine waters presently covered by sea ice may become partially ice-free yearround or at certain times of the year. A mosaic of conditions, that range from open to fully ice-covered waters, is already found in polar areas known as polynyas, which have recently been considered as model systems to investigate how global warming may affect polar ecosystems in a few decades (Yager et al.

·E-mail: aad839@agora.ulaval.ca
1995). Phytoplankton assemblages in high latitudes have been previously described, during spring and summer, for open waters (Diel \& Buma 1989, Hirche et al. 1991, Legendre et al. 1993), mixed ice cover (Baumann 1987, Gradinger \& Baumann 1991, Smith \& Brightman 1991) and ice-covered conditions (Gradinger \& Baumann 1991, Robineau et al. 1994). Recently, a comparative study of primary production in the 3 types of environment was conducted in the Northeast Water Polynya (Smith 1995).

The Northeast Water (NEW) is located in the Greenland Sea, where it extends from $77^{\circ}$ to $81^{\circ} \mathrm{N}$ on the North East Greenland Shelf, at the southern limit of the permanent Arctic ice pack. The region is characterized 
by the presence of a recurring polynya, i.e. the ice cover opens every year from April through September (Schneider \& Budéus 1994, Ramseier et al. 1996). In the NEW, environmental and phytoplankton characteristics exhibit complex spatio-temporal patterns (Lara et al. 1994, Smith 1995, Smith et al. 1995), so that it is difficult to stratify these characteristics by reference to either hydrographic domains (e.g. Polar vs Atlantic waters, deep troughs vs banks), hydrodynamic conditions (e.g. vertically mixed vs stratified water column) or ice cover (i.e. open vs ice-covered waters).

An alternative approach consists in grouping stations on the basis of selected biological characteristics. irrespective of time or space, and comparing environmental and biological variables among the resulting groups. Several studies, describing the production of phytoplankton in polar waters and under various ice cover conditions, have grouped stations on the basis of the taxonomic composition of phytoplankton assemblages (e.g. Schandelmeier \& Alexander 1981, Gradinger \& Baumann 1991, Lara et al. 1994). However, this approach does not take into account the fact that, in some ecosystems, phytoplankton that dominate the standing stock do not necessarily contribute proportionally to the primary production (e.g. tropical neritic waters and upwelling areas; Tremblay \& Legendre 1994).

The approach used in the present paper consists in grouping stations on the basis of size differential phytoplankton production and biomass. This approach comes from the fact that phytoplankton sizes determine, in part, their photosynthetic ability (Morel \& Bricaud 1981, Kiørboe 1993), nutrient uptake characteristics (Berg \& Purcell 1977, Kiørboe 1993), exudation (Bjørnsen 1988), losses to grazing (Fortier et al. 1994, Sherr \& Sherr 1994), and sinking rates (Smayda 1970). Hence, it allows us to investigate the environmental control and fate of phytoplankton production. Legendre \& Le Fèvre (1991) proposed a typology of phytoplankton production regimes based on the various possible combinations between the standing stock and production of large $(>5 \mu \mathrm{m})$ and small $(<5 \mu \mathrm{m})$ phytoplankton The 5 resulting regimes are: (1) production and biomass dominated by large phytoplankton, (2) production by small and large phytoplankton and biomass dominated by large phytoplankton, (3) production and biomass shared by small and large phytoplankton, (4) production by small and large phytoplankton and biomass dominated by small phytoplankton, and (5) production and biomass dominated by small phytoplankton.

Little is presently known concerning the contribution of phytoplankton size fractions to primary production in the Arctic (see review by Tremblay \& Legendre 1994). One could assume that open waters in the NEW should be somewhat similar to those observed by
Hirche et al. (1991) and Legendre et al. (1993) in the Greenland Sea $\left(75^{\circ} \mathrm{N}\right)$, where large and small phytoplankton each accounted for ca 35 to $65 \%$ of total primary production and biomass. This situation corresponds to Regime 3. Phytoplankton production in mixed ice conditions and in ice-covered waters of the NEW should have characteristics similar to those found in the Fram Strait $\left(77^{\circ}\right.$ to $78^{\circ} \mathrm{N}$; Smith et al. 1987 , Gradinger \& Baumann 1991, Smith \& Brightman 1991). There, in ice-covered waters, phytoplankton biomass and production were dominated by small flagellates, corresponding to Regime 5. In contrast, in mixed ice conditions, phytoplankton biomass and production consisted of moderate blooms of large diatoms and/or colonies of Phaeocystis, which corresponds to Regime 1. Previous reports of phytoplankton taxonomy in the NEW for summer 1984-85 (Baumann 1987, Diel \& Buma 1989), spring 1991 (Lara et al. 1994), and summer 1992 (Smith et al. 1995) are consistent with these expectations. It is thus hypothesized that production Regimes 1, 3 and 5, as defined by Legendre \& Le Fèvre (1991), are likely to develop in the NEW, in response to the different combinations of environmental conditions encountered there.

\section{MATERIALS AND METHODS}

Study area and sampling programme. Sampling was conducted in the NEW, from 23 May to 31 July 1993 (RV 'Polarstern' cruises ARK IX/2 and 3), within the framework of the International Arctic Polynya Programme. In the NEW, the East Greenland Shelf includes a large offshore bank (Belgica Bank) surrounded by a system of troughs, which is partitioned in 3 sections: the Belgica, Norske and Westwind Troughs (Fig. 1). Water circulation in the NEW is characterized by an anticyclonic (clockwisel gyre, circling Belgica Bank along the system of troughs. Phytoplankton were sampled at 58 stations. These covered a wide range of ice, hydrodynamic, and nutrient conditions. Positions of stations sampled for each variable appear in Fig. 4 Ice concentrations were monitored using a Special Sensor Microwave/Imager (SSM/I) on board the Defense Meteorological Satellite Program platform F-11, which provided daily estimates of percent ice cover $(\Phi)$ at the scale of $25 \times 25 \mathrm{~km}$ (Garrity \& Ramseier 1994). Photosynthetically available radiation (PAR: 400 to $700 \mathrm{~nm}$ ) was recorded on deck at 30 min intervals, using a LI-COR 190 SA quantum meter.

Sampling and laboratory analyses. At each station, water was sampled using a rosette sampler equipped with a Seabird 911+ CTD system (results in Budéus et al. 1994), a fluorescence probe (Dr Haardt Instruments). a LI-COR 185 B underwater quantum PAR meter, and 

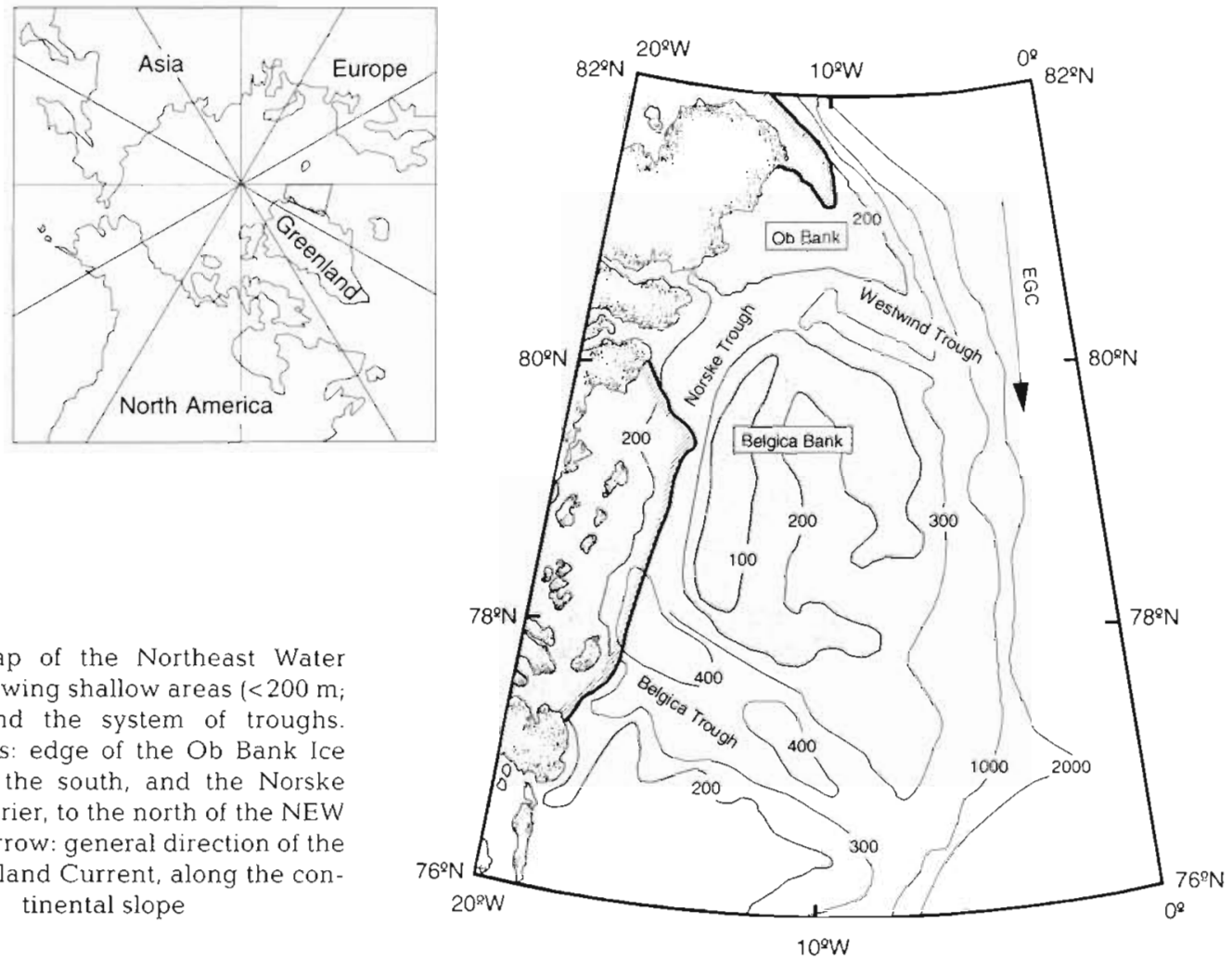

Fig. 1 Map of the Northeast Water (NEW), showing shallow areas $(<200 \mathrm{~m}$; shaded) and the system of troughs. Heavy lines: edge of the Ob Bank Ice Barrier, to the south, and the Norske Der Ice Barrier, to the north of the NEW Polynya. Arrow: general direction of the East Greenland Current, along the continental slope

twelve 121 Niskin bottles. Water samples were collected at 8 depths, 7 of which corresponded to irradiances $100,50,30,15,5,1$, and $0.1 \%$ of surface PAR and one was at the depth of maximum chlorophyll a (chl a) concentration (i.e. maximum in vivo fluorescence). Subsamples were immediately drawn from the Niskin bottles for determination of nutrients and estimation of various phytoplankton variables. These included particulate organic carbon (POC), chl a, phytoplankton identification and enumeration, primary production, and settling rates.

Dissolved inorganic nutrients (nitrate, nitrite, ammonium, phosphate, silicate) were determined on board the ship using a Technicon AutoAnalyzer II System (results in Kattner et al. 1994). Subsamples (200 ml) for the determination of chl a were filtered in parallel on $25 \mathrm{~mm}$ Whatman GF/F filters (total phytoplankton biomass: $B_{\top}$ ) and $25 \mathrm{~mm}$ Poretics polycarbonate membranes with $5 \mu \mathrm{m}$ nominal pore size (biomass of large phytoplankton: $B_{\mathrm{L}}$ ). Chl a was measured using a Turner fluorometer (model 112), after 24 h extraction in $90 \%$ acetone at $5^{\circ} \mathrm{C}$ without grinding (Parsons et al. 1984). Subsamples collected at the surface and at the depth of maximum fluorescence were preserved with acidic Lugol's solution for cell identification and enumeration with an inverted microscope (Lund et al. 1958). Daily primary production was estimated from $7(100,50,30,15,5,1$, and $0.1 \%$ of surface PAR $)$ or
4. photic depths $(100,50,30$, and $5 \%$ of surface PAR) depending on the space available in the incubators, using the ${ }^{14} \mathrm{C}$ uptake method (Parsons et al. 1984). Inoculated bottles were placed for $24 \mathrm{~h}$ in Plexiglas deck incubators that simulated in situ light and temperature conditions. At the end of incubations, the total volume of each bottle was split in two $250 \mathrm{ml}$ aliquots, which were filtered on GF/F (total phytoplankton production: $P_{\Upsilon}$ ) and Poretics $5 \mu \mathrm{m}$ filters (production of large phytoplankton: $P_{\mathrm{L}}$ ), respectively. The filters were acidified to remove inorganic carbonated precipitates. During the incubations, the simulated in situ irradiance was not corrected for the attenuation of PAR by snow, ice, and ice algae. To correct a posteriori for this effect, all values of integrated primary production reported in this paper were multiplied by the percentage of open water in the sampling area (see arguments in Smith 1995).

Settling rates of phytoplankton were estimated using 2 large settling columns $19 \mathrm{~cm}$ diameter and $60 \mathrm{~cm}$ height; Bienfang 1981) filled with subsamples (ca $4000 \mathrm{ml}$ from the depth of maximum in vivo fluorescence. Settling determinations were done in duplicate. To keep the 2 columns in darkness and at a temperature close to that in situ, these were kept inside an opaque sleeve with running seawater pumped at $8 \mathrm{~m}$ Particles were allowed to settle for 2 to $6 \mathrm{~h}$, depending on the abundance of phytoplankton. The top and bot- 
tom fractions in the columns were then collected for chl a determinations (see above).

Calculations. The depth of the surface mixed layer $\left(z_{\mathrm{m}}\right)$ was determined by visual inspection of the vertical density $\left(\sigma_{l}\right)$ profile. The value of fresh water content (FWC) was determined as the thickness (in metres) of a fresh water column that would have to be mixed into the surface $30 \mathrm{~m}$ of a water column with $\mathrm{S}=32.5$ in order to achieve the observed salinity profile (Budéus et al. 1994).

Because only relative underwater PAR was measured, absolute underwater PAR was calculated from the incident solar radiation measured on deck ( $E_{s i}$ mol photons $\mathrm{m}^{-2} \mathrm{~d}^{-1}$ ). Solar radiation passing through the water surface $\left(E_{0}\right)$ is a function of the reflectivity of open water and of the attenuation of $E_{\mathrm{s}}$ by snow, ice and ice algae. $E_{0}$ was calculated taking into account the relative areas covered by ice $(\Phi)$ and of open water $(1-\Phi)$ and their respective attenuation factors:

$$
E_{0}=E_{\mathrm{s}}-\left[(1-\Phi)\left(k_{\mathrm{ow}} E_{\mathrm{s}}\right)+(\Phi)\left(k_{\Phi} E_{\mathrm{s}}\right)\right]
$$

where $k_{\text {ow }}$ and $k_{\Phi}$ are the attenuation factors of $E_{s}$ due to open water reflectivity and to ice-cover, respectively. Given a mean solar elevation angle of $55^{\circ}$ (calculated from the latitude and sampling period), $k_{\text {or }}$ was estimated to be $4.3 \%$ in the NEW Polynya (see Table 2.1 in Kirk 1983). The amount of PAR that passed through the snow, ice and ice algae was measured at a few stations using a LI-COR 185 B underwater PAR meter, where it averaged $9 \%$ of the incident solar radiation. Thus, $k_{\Phi}$ was estimated to be, on average, $91 \%$. Average irradiance in the euphotic zone $\left(E_{\left(0-z_{\text {eu }}\right)}\right)$ i.e. from the surface down to $z_{\text {eu }}$, which is the depth where PAR is $0.01 E_{0}$ ) was calculated as $0.22 E_{0}$ (Vincent \& Roy 1993)

The potential sedimentation rate of phytoplankton ( $\mathrm{mg}$ chl a $\mathrm{m}^{-2} \mathrm{~d}^{-1}$ ) was calculated as the product of chl a concentration at the depth of maximum in vivo fluorescence ( $\mathrm{mg}$ chl $\mathrm{a} \mathrm{m}^{-3}$ ) with the settling rate ( $\mathrm{m} \mathrm{d}^{-1}$ ), calculated using the formulae of Bienfang (1981). Units were transformed into $\mathrm{mg} \mathrm{C} \mathrm{m} \mathrm{m}^{-2} \mathrm{~d}^{-1}$ using the slope of the regression between POC and chl a for all data in the euphotic zone.

Stations were grouped according to the contributions of large phytoplankton to total primary production $\left(P_{\mathrm{L}} / P_{\mathrm{T}}\right)$ and biomass $\left(B_{\mathrm{L}} / B_{\mathrm{T}}\right)$. Values of $P_{\mathrm{L}} / P_{\mathrm{T}}$ and $B_{\mathrm{L}} / B_{\mathrm{T}}$ were used to calculate similarities (Gower's coefficient) between all pairs of stations (Legendre \& Legendre 1983). The resulting matrix was analyzed by agglomerative hierarchical clustering (Lance \& Williams 1966, 1967), using the complete linkage algorithm. Computations were performed with the $\mathrm{R}$ software (Legendre \& Vaudor 1991).

Differences among groups of stations, for various physical, chemical and biological variables, were assessed using nonparametric tests (SAS software;
Schlotzhauer \& Littell 1987). Nonparametric tests were preferred over parametric tests because the variables were not distributed normally. Differences between 2 groups were tested using the Mann-Whitney U-test (Zar 1984). The procedure LOGISTIC in the SAS software was used to assess which of the physical and chemical variables best discriminated between the groups of stations. Only variables that significantly differed between the groups were used to calculate the logistic regression (Legendre \& Legendre 1983). These procedures are the nonparametric equivalents of 1-way ANOVAs and discriminant analyses, generally used for normally distributed quantitative data.

\section{RESULTS}

\section{Physical and chemical environment}

During the whole sampling period, the NEW Polynya was limited to the north by a permanent ice boundary, the Ob Bank Ice Barrier, and to the south by the Norske Øer Ice Barrier Fig. 2a illustrates the extent of open waters (i.e. the polynya) at the beginning $(27$ May) and at the end (27 July) of the expedition. Waters started to open in mid-May, at the edge of the 2 ice barriers, thus forming 2 small polynyas (Fig. $2 a$; heavy line M). The easternmost limit of the NEW Polynya (Fig. 2a; heavy line J) was maintained by ice floes which were advected out of the polynya and from the East Greenland Current (Fig. 1) and accumulated in a pack ice structure over Belgica Bank. Sampling was over the complete range of ice cover (from 0 to $100 \%$ ), with a predominance of stations corresponding to heavy ice conditions (from 60 to $80 \%$ ). Minimum values of FWC $(<0.25 \mathrm{~m})$, which is an index of melt water run-off and sea ice melting (see 'Materials and methods'), were found in the southern region of the NEW Polynya (Fig. 2b)

In May and June, surface (0 to $2 \mathrm{~m}$ ) concentrations of nitrate (Fig. 2c) ranged from 1.5 to $2.5 \mathrm{mmol} \mathrm{m}^{-3}$ near the coast and from 3 to $4 \mathrm{mmol} \mathrm{m}^{-3}$ in most of the remainder of the study area. In July, surface concentrations of nitrate were almost depleted in the northern part of the NEW Polynya and along the coast of Greenland (Fig. 2d). At that time, maximum surface concentrations of nitrate $\left(>3 \mathrm{mmol} \mathrm{m}{ }^{-3}\right.$; Fig $2 \mathrm{~d}$ ) were in the tongue of low FWC waters $\left(<0.25 \mathrm{~m}_{i}\right.$ Fig. $\left.2 \mathrm{~b}\right)$, hence in the southern region of the NEW Polynya. Surface concentrations of silicate, phosphate and ammonium also decreased significantly from 23 May to 31 July, but they never reached depletion (Kattner \& Budéus 1996). $E_{\mathrm{s}}$ varied from 20 to $140 \mathrm{~mol}$ photons $\mathrm{m}^{-2} \mathrm{~d}^{-1}$, the maximum values occurring in the days that followed the summer solstice. 


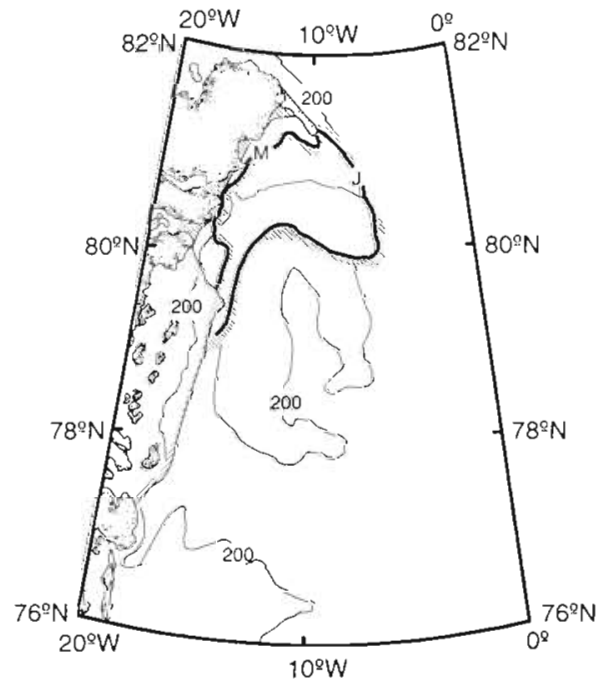

a. Eastern limit of open waters

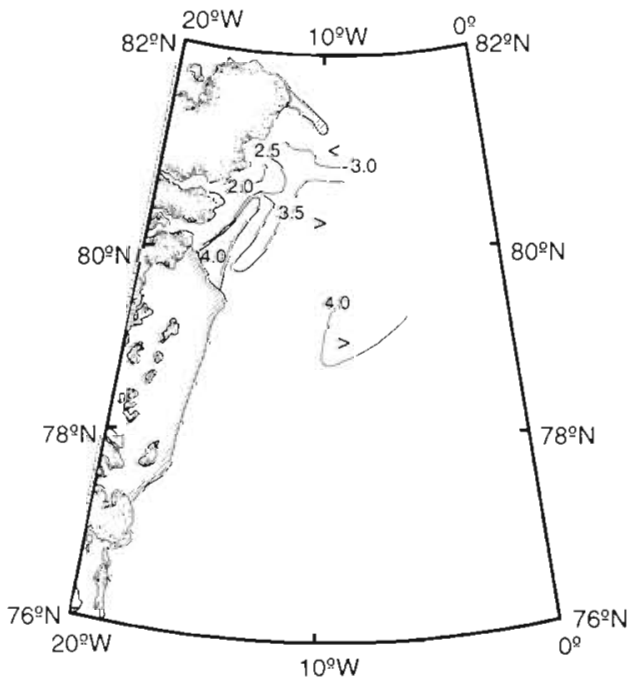

c. Nitrate (23 May-24 June) $\left(\mathrm{mmol} \mathrm{m}^{-3}\right)$

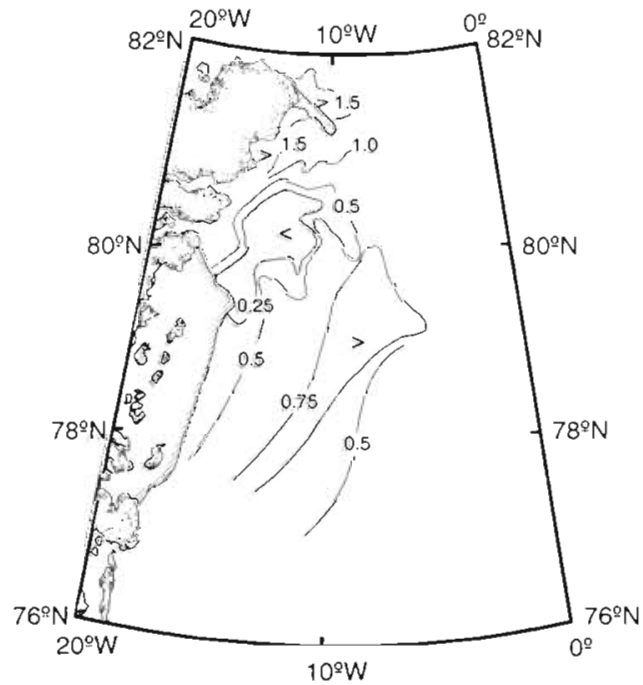

b. Freshwater content (m)

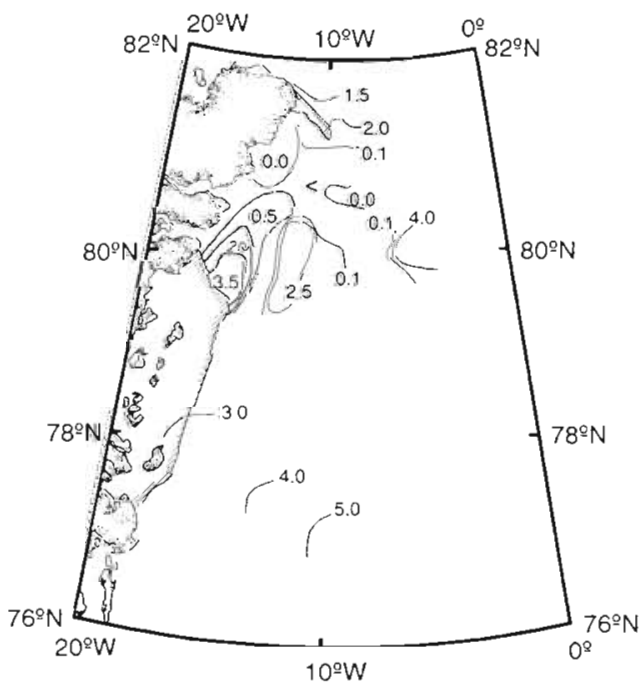

d. Nitrate (27 June-31 July) ( $\mathrm{mmol} \mathrm{m}^{-3}$ )

Fig. 2. Horizontal distributions of some physical characteristics in the euphotic zone. (a) Extent of open waters during the 1993 expedition in the Northeast Water (from NOAA-AVHRR satellite images). Hatched lines: edge of the ice; heavy lines: eastern limit of open waters on (M) 27 May and (J) 27 July. Open waters were limited to the north by the Ob Bank Ice Barrier, to the south by the Norske Øer Ice Barrier, to the west by land fast ice, and to the east by pack ice. (b) Fresh water content in the upper $30 \mathrm{~m}$ of the water column in July, expressed as the height of fresh water in metres (reproduced from Budéus et al. 1994). Surface concentrations of nitrate from (c) 23 May to 24 June and (d) 27 June to 31 July were reproduced from Kattner \& Budéus (1996). Shaded areas, which extend north of the Norske Øer Ice Barrier: tongues of (b) low fresh water content and (c, d) high surface nitrate concentration

\section{Regimes of phytoplankton production}

Three distinct groups of stations were identified on the basis of size-fractionated phytoplankton biomass (chl a) and production, using complete linkage clustering. These 2 criteria were plotted in a productionbiomass ( $P-B$ ) diagram (Fig. 3), which illustrates the 3 resulting groups. In the upper right-hand cluster $(\bullet)$ the standing stock and production are both dominated by large phytoplankton. In the intermediate cluster $(0)$, the standing stock is dominated by large phytoplankton and production is shared between the 2 size fractions. In the lower left-hand cluster $(+)$, small phytoplankton dominate both the standing stock and 


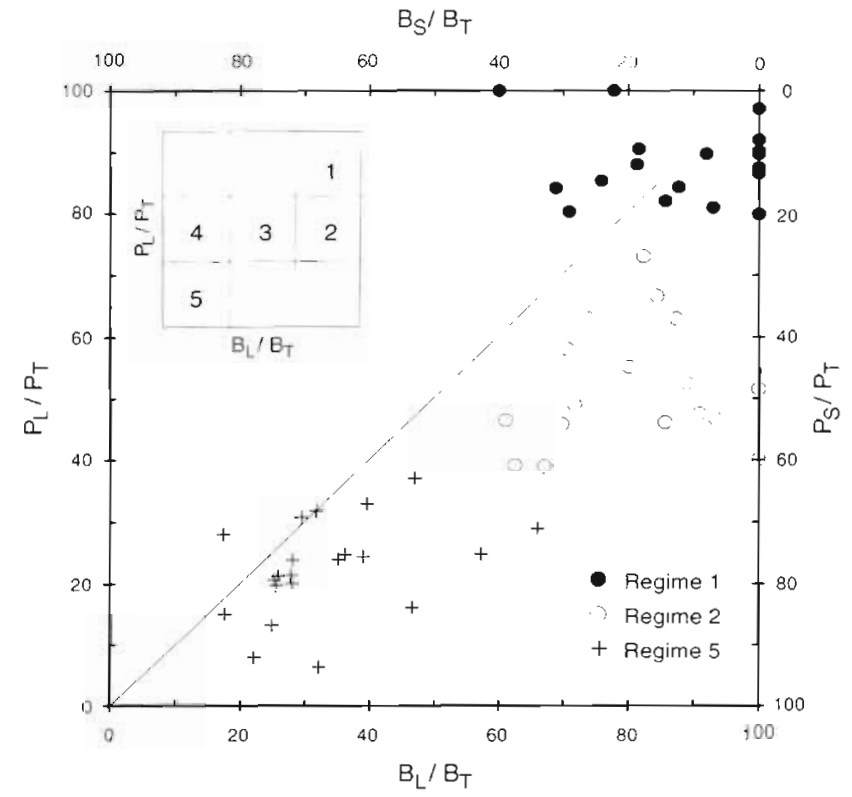

Fig. 3. Production-biomass $(P-B)$ diagram (58 stations). Lefthand and lower axes: $P_{L} / P_{T}$ (production of large/total phytoplankton) and $B_{\mathrm{L}} / B_{\mathrm{T}}$ (biomass of large/total phytoplankton). Right-hand and upper axes: $P_{\mathrm{S}} / P_{\mathrm{T}}$ (production of small/total phytoplankton) and $B_{\mathrm{S}} / B_{\mathrm{T}}$ (biomass of small/total phytoplankton). Three clusters of stations are identified, each with a distinct symbol. Inset: regions of the diagram corresponding to the 5 phytoplankton production regimes proposed by Legendre \& Le Fèvre (1991). The main diagonal $\left(P_{\mathrm{L}} / P_{\mathrm{T}}=B_{\mathrm{L}} / B_{\mathrm{T}}\right)$ corresponds to a balance between production and export for the 2 size fractions (Tremblay \& Legendre 1994)

production. Given that sectors of the $P-B$ diagram (inset; Fig. 3) correspond to the different phytoplankton production regimes as proposed by Legendre \& Le Fèvre (1991; see 'Introduction'), the 3 clusters are iden-

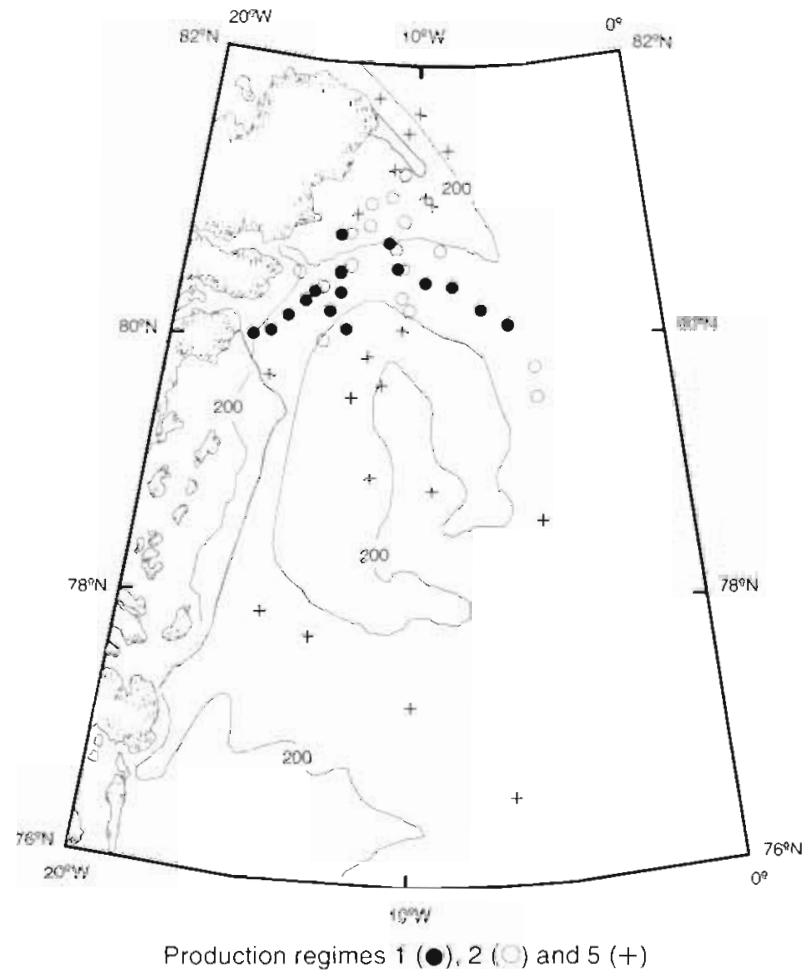

Fig. 4. Horizontal distribution of the 3 production regimes identified in Fig. 3. Hatched lines: edges of the ice barriers

tified in the remainder of the text as Regime $1(\mathbf{0})$, Regime $2(0)$, and Regime $5(+)$. The horizontal distribution of the stations belonging to each regime is shown in Fig. 4

Significant differences in physical, chemical, and biological variables between regimes are summarized in Tables $1 \& 2$. Since no surface stratification was

Table 1 Modian values and ranges (in parentheses) of physical and chemical variables at stations belonging to the 3 regimes Differences between Regimes 1 and 2 and between Regimes 1-2 and 5: nonparametnc comparison tests either rejected the hypothesis of equal medians ( $>$ or $<$ ) or failed to reject it $(\cong)$

\begin{tabular}{|c|c|c|c|c|c|c|c|}
\hline Variable & Symbol & Units & Regime $1(\bullet)$ & vs & $\begin{array}{l}\text { Median valu } \\
\text { Regime } 2(0)\end{array}$ & vs & Regime $5(+)$ \\
\hline Area covered by 1 ce & $\Phi$ & $\%$ & $\begin{array}{c}51 \\
(19-91)\end{array}$ & $\equiv$ & $\begin{array}{c}49 \\
(18-91)\end{array}$ & $<$ & $\begin{array}{c}71 \\
(52-100)\end{array}$ \\
\hline $\begin{array}{l}\text { Average irradiance } \\
\text { in the euphotic zone }\end{array}$ & $E_{\left.\mid 0-z_{\mathrm{eu}}\right)}$ & mol photons $\mathrm{m}^{-2} \mathrm{~d}^{-1}$ & $\begin{array}{c}7 \\
(1-27)\end{array}$ & $\equiv$ & $\begin{array}{c}7 \\
(1-23)\end{array}$ & $>$ & $(0.3-18)$ \\
\hline $\begin{array}{l}\text { Mean temperature } \\
\text { in the euphotıc zone }\end{array}$ & $T_{\left(0-z_{e u} \mid\right.}$ & ${ }^{\circ} \mathrm{C}$ & $\begin{array}{c}-0.3 \\
(-1.7-4.2)\end{array}$ & $\cong$ & $\begin{array}{c}0.5 \\
(-1.1-5.2)\end{array}$ & $>$ & $\begin{array}{c}-12 \\
(-1.7-0.3)\end{array}$ \\
\hline Surface nitrate concentration & $\mathrm{NO}_{3}$ & $\mathrm{mmol} \mathrm{m} \mathrm{m}^{-3}$ & $\begin{array}{c}2 \\
(0.02-4.03)\end{array}$ & $>$ & $(0.01-3.79)$ & $<$ & $\begin{array}{c}4 \\
(2.03-5.00)\end{array}$ \\
\hline Depth of the muxed layer & $z_{\mathrm{m}}$ & $\mathrm{m}$ & $\begin{array}{c}12 \\
(0-25)\end{array}$ & $<$ & $\begin{array}{c}34 \\
(10-75)\end{array}$ & & - \\
\hline$z_{\mathrm{m}} / z_{\mathrm{Cu}}$ & $z_{\mathrm{rII}} / z_{\mathrm{eu}}$ & & $\begin{array}{c}0.3 \\
(0-0.8)\end{array}$ & $<$ & $\begin{array}{c}0.8 \\
(0.5-3.1)\end{array}$ & & - \\
\hline
\end{tabular}


Table 2. Median values and ranges (in parentheses) of bıological variables at stations belonging to the 3 regimes. Differences between Regimes 1 and 2 and between Regimes 1 to 2 and 5: nonparamctric comparison tests either rejected the hypothesis of equal medians $(>$ or $<$ ) or failed to reject it $(\Leftrightarrow)$

\begin{tabular}{|c|c|c|c|c|c|c|c|}
\hline Variable & Symbol & Units & Regime $1(\bullet)$ & vs & $\begin{array}{r}\text { Median val } \\
\text { Regıme } 2(0)\end{array}$ & VS & Regime $5(t)$ \\
\hline Depth of the chl a maximum & $z_{\mathrm{c}+h l}$ & $\mathrm{~m}$ & $\begin{array}{c}9 \\
(2-12)\end{array}$ & $<$ & $\begin{array}{c}16 \\
(5-46)\end{array}$ & $\cong$ & $\begin{array}{c}12 \\
(2-26)\end{array}$ \\
\hline Chl a biomass & $B_{\mathrm{T}}$ & $\mathrm{mg} \mathrm{chl} \mathrm{a} \mathrm{m}^{-2}$ & $\begin{array}{c}16 \\
(1-47)\end{array}$ & $\equiv$ & $\begin{array}{c}23 \\
(5-44)\end{array}$ & $>$ & $\begin{array}{c}8 \\
(1-21)\end{array}$ \\
\hline $\begin{array}{l}\text { Contribution of large cells to } \\
\text { chl a biomass }\end{array}$ & $B_{\mathrm{L}} / B_{\mathrm{T}}$ & $\%$ & $\begin{array}{c}85 \\
(69-100)\end{array}$ & $\cong$ & $\begin{array}{c}83 \\
(61-100)\end{array}$ & $>$ & $\begin{array}{c}33 \\
(17-66)\end{array}$ \\
\hline Daily primary production & $p_{\mathrm{T}}$ & $\mathrm{mg} C \mathrm{~m}^{-2} \mathrm{~d}^{-1}$ & $\begin{array}{c}544 \\
(32-1733)\end{array}$ & $\cong$ & $\begin{array}{c}543 \\
(153-1433)\end{array}$ & $>$ & $\begin{array}{c}212 \\
(13-547)\end{array}$ \\
\hline $\begin{array}{l}\text { Contribution of large cells to } \\
\text { primary production }\end{array}$ & $P_{\mathrm{L}} / P_{\mathrm{T}}$ & $\%$ & $\begin{array}{c}83 \\
(80-100)\end{array}$ & $>$ & $\begin{array}{c}53 \\
(39-73)\end{array}$ & $>$ & $\begin{array}{c}23 \\
(6-37)\end{array}$ \\
\hline Potential sedimentation rate & Sed & $m g C m^{-2} d^{-1}$ & $\begin{array}{c}248 \\
(43-327)\end{array}$ & $>$ & $\begin{array}{c}84 \\
(14-177)\end{array}$ & $>$ & $\begin{array}{c}43 \\
(0-116)\end{array}$ \\
\hline
\end{tabular}

observed at stations belonging to Regime 5, values of $z_{n}$ and $z_{\mathrm{m}} / z_{\mathrm{eu}}$ are not reported for that regime. All other physical and biological variables (except the depth of the chl a maximum) differed between Regime 5 and the other 2 regimes. Surface $\mathrm{NO}_{3}, z_{\mathrm{m}}$, and $z_{\mathrm{m}} / z_{\mathrm{eu}}$ were the only environmental variables that differed between Regimes 1 and 2. Maximum chl a was found at greater depth in Regime 2 compared to Regime 1 and the contributions of large phytoplankton to total production and potential sedimentation rates were larger in Regime 1 than 2 (Table 2). The dominant taxa in Regimes 1, 2 and 5 (Table 3) were pennate diatoms, centric diatoms, and flagellates, respectively. Ice taxa were present under all regimes, but were more abundant in Regimes 1 and 2 (Table 3). Abundances of dinoflagellates and flagellates were similar in the 3 regimes, whereas Phaeocystis spp. was more frequently observed in Regime 2 but never dominated the assemblage. Ciliates and ameboid forms were less abundant in Regime 2.

The vertical distributions of chl $a, \sigma_{t}$, $\mathrm{NO}_{3}$ and $z_{\text {eu }}$ are shown for 3 stations, each being representative of a given regime (Fig. 5). In Regime 1, near-surface stratification was strong, nutrients were abundant (ca 4 mmol $\mathrm{NO}_{3} \mathrm{~m}^{-3}$ ), biomass was dominated by large phytoplankton (>5 $\mu \mathrm{m})$, and maximum chl a was located near the surface. In Regime 2, surface waters were strongly influenced by melt water $\left(\sigma_{t}<24\right)$ and stratification was more complex than in Regime 1; small phytoplankton dominated close to the surface where nutrients were depleted (ca $1 \mathrm{mmol} \mathrm{NO}_{3} \mathrm{~m}^{-3}$ ), whereas large phytoplankton dominated in the pycnocline where nutrients were relatively abundant (ca $3 \mathrm{mmol} \mathrm{NO}_{3} \mathrm{~m}^{-3}$ ). In Regime 5, the water column was not stratified close to the surface, nutrients were abundant (ca $4 \mathrm{mmol} \mathrm{NO}_{3}$

Table 3. Mean $\left(\times 10^{6}\right.$ cells $\left.\mathrm{m}^{-3}\right)$ and percent abundances (in parentheses) of phytoplankton taxa, ciliates, and ameboid forms corresponding to each production regime. Samples were collected at the depth of maximum chl a fluorescence

\begin{tabular}{|c|c|c|c|}
\hline \multirow{2}{*}{ Taxon } & \multicolumn{3}{|c|}{ Mean values (and \% abundance) } \\
\hline & Regime $1(0)$ & Regime $2(0)$ & Regime $5(+)$ \\
\hline Total & $3098(100)$ & $3171(100)$ & $1066(100)$ \\
\hline Flagellates $<5 \mu \mathrm{m}$ & $624(20)$ & $589(18)$ & $490(46)$ \\
\hline Flagellates $>5 \mu \mathrm{m}$ & $167(5)$ & $188(5)$ & $220(21)$ \\
\hline Phaeocystis sp. & $0(0)$ & $12(1)$ & $1(<1)$ \\
\hline Pennate diatoms & $1580(51)$ & $937(30)$ & $54(5)$ \\
\hline Fragilaria spp. & 621 & 269 & 14 \\
\hline Fragilariopsis spp. & 628 & 475 & 5 \\
\hline Navicula spp."i & 110 & 35 & 1 \\
\hline Nitzschia spp. ${ }^{a}$ & 9 & 97 & 1 \\
\hline Pseudo-nitzschia spp. & 23 & 11 & 2 \\
\hline Others & 189 & 50 & 31 \\
\hline Centric diatoms & $509(16)$ & $1386(44)$ & $18(2)$ \\
\hline Chaetoceros spp. & 286 & 1142 & 14 \\
\hline Melosira spp. ${ }^{A}$ & 52 & 4 & 1 \\
\hline Thalassiosira spp. & 46 & 37 & 2 \\
\hline Others & 125 & 203 & 1 \\
\hline Dinoflagellates & $31(1)$ & $37(1)$ & $32(3)$ \\
\hline Culiates and ameboid forms & $187(7)$ & $22(1)$ & $251(23)$ \\
\hline
\end{tabular}



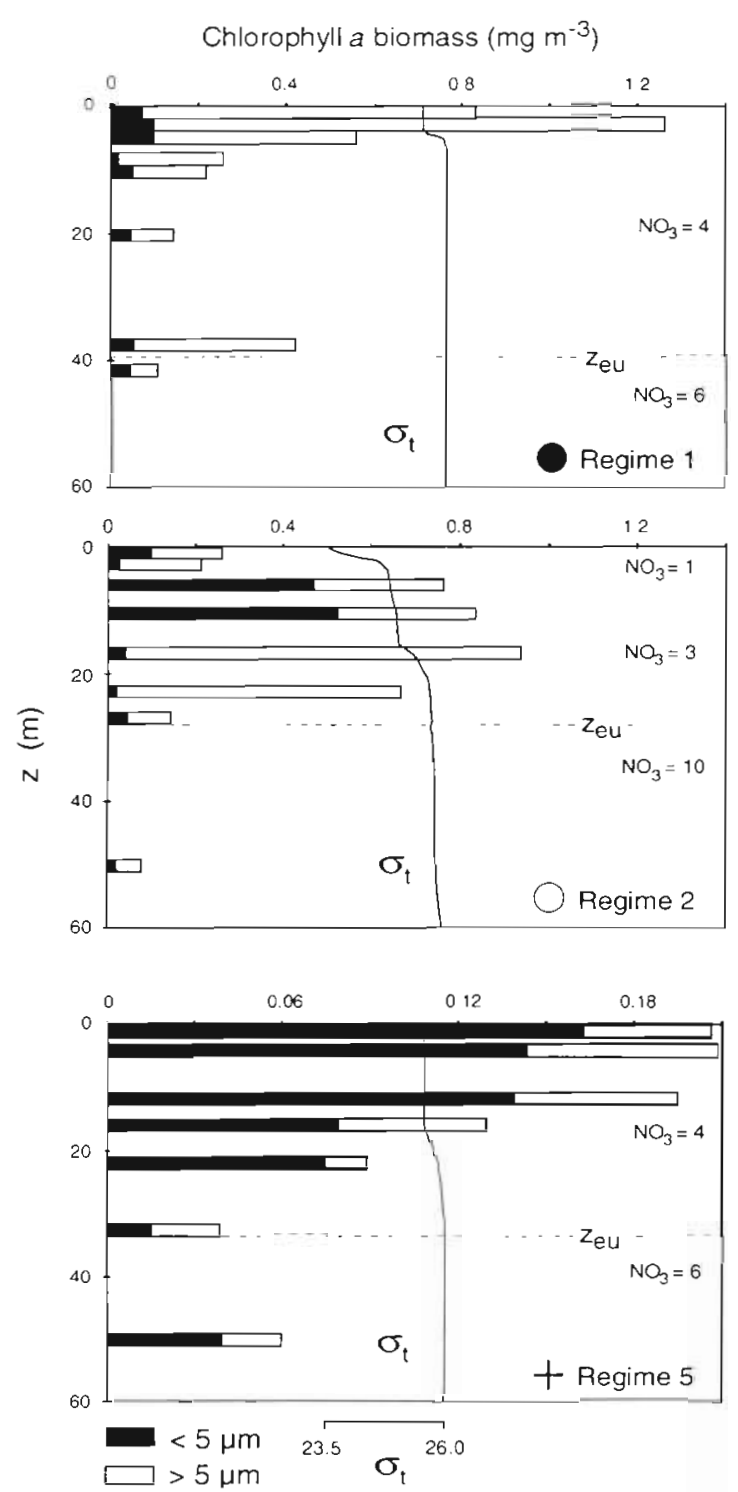

Fig. 5. Vertical distributions of total chl $a_{1} \sigma_{1}, \mathrm{NO}_{3}$ and $z_{\mathrm{e} i \mathrm{j}}$ for 3 stations, each being representative of a given production regime (see Fig. 3). Stacked bars represent the contribution of small (solid bars) and large (open bars) phytoplankton to total chl a biomass (solid + open bars). Concentrations of $\mathrm{NO}_{3}$ in $\mathrm{mmol} \mathrm{m} \mathrm{m}^{-3}$

$\left.\mathrm{m}^{-3}\right)$ and small phytoplankton $(<5 \mu \mathrm{m})$ dominated the biomass. Values of chl $a, z_{\mathrm{m}}, \mathrm{NO}_{3}$ and $z_{\mathrm{eu}}$ at the 3 representative stations (Fig. 5) are consistent with median values for the 3 regimes (Tables $1 \& 2$ ). At the 3 stations, $z_{\text {eu }}$ was deeper than $z_{\mathrm{m}}$ but, occasionally, stations from Regimes 5 and 2 had $z_{\mathrm{m}} / z_{\text {eu }}$ values $>1$.

Results from logistic regression analyses (Table 4) identified $E_{\left(0-z_{e u}\right)}$ as the physical variable that best explained the difference between Regime 5 and combined Regimes 1 and 2. Nitrate, ice cover, and mean
Table 4. Results of logistic regressions testing which of the physical variables best discriminated between Regimes 1 and 2 and between Regimes $1-2$ and 5. Variables that discriminated best between 2 groups are those with lowest associated probability. ns: not significant, variables with probabilities $>0.1$

\begin{tabular}{|c|c|c|c|}
\hline \multirow[t]{2}{*}{ Variable } & \multirow[t]{2}{*}{ Symbol } & \multicolumn{2}{|c|}{ Probability } \\
\hline & & $1-2$ vs 5 & 1 vs 2 \\
\hline $\begin{array}{l}\text { Average irradiance } \\
\text { in the euphotic zone }\end{array}$ & $E_{(0-z)}$ & 0.001 & ns \\
\hline Surface nitrate & $\mathrm{NO}_{3}$ & 0.063 & ns \\
\hline Area covered by ice & $\Phi$ & ns & ns \\
\hline $\begin{array}{l}\text { Average temperature } \\
\text { in the euphotic zone }\end{array}$ & $T_{\left.i 0-z_{e u}\right)}$ & ns & ns \\
\hline $\begin{array}{l}\text { Depth of the surface } \\
\text { mixed layer }\end{array}$ & $z_{\mathrm{m}}$ & ns & 0.058 \\
\hline
\end{tabular}

temperature in the euphotic zone did not significantly discriminate between Regime 5 and the other 2 regimes. The difference between Regimes 1 and 2 was explained by $z_{\mathrm{m}}$ only.

\section{DISCUSSION}

\section{Methodological considerations}

In this study, the threshold between small and large phytoplankton was set at $5 \mu \mathrm{m}$, as in Cushing (1989) and Legendre (1990). We assumed that filters of nominal pore size $5 \mu \mathrm{m}$ (polycarbonate membranes) retained only particles $>5 \mu \mathrm{m}$ diameter, length or width, and conversely did let through smaller particles $(<5 \mu \mathrm{m})$. However, during filtration, a significant proportion of small particles can be retained in the large size fraction, by adhesion to other particles or to the filter itself (Malone et al. 1979, Logan 1993, 1994). Indeed, long chains of diatoms and mucilaginous flagellates (e.g. Phaeocystis) are known to cause filter clogging. It could thus be argued that the contribution of large phytoplankton to the biomass or production was overestimated at some stations and, conversely, that the contribution of the small fraction was underestimated. If that problem was important, these stations could have been shifted up and to the right in the $P$ - $B$ diagram (Fig. 3). However, at these stations, the contribution of (large) blooming species to the production and standing stock was so large that overestimation of large phytoplankton was probably not very important

Surface currents in the NEW ranged from 0.1 to $0.3 \mathrm{~m} \mathrm{~s}^{-1}$, so that the horizontal excursion of phytoplankton could have reached 1.0 to $26 \mathrm{~km}$ during $1 \mathrm{~d}$. It follows that the scale at which the ice cover was esti- 
mated ( $25 \times 25 \mathrm{~km}$; see 'Materials and methods') is appropriate to describe the light conditions encountered by the phytoplankton over $24 \mathrm{~h}$.

\section{Regimes of phytoplankton production}

Stations in the NEW were grouped on the basis of the differential contributions of large and small phytoplankton to total primary production and biomass. These 2 criteria were hypothesized (Legendre \& Le Fèvre 1991) to reflect the environmental control and the fate of phytoplankton production. On the basis of these criteria, Tremblay \& Legendre (1994) derived an interpretation in terms of export. In the present paper, the 2 criteria are used to identify phytoplankton production regimes present in the NEW, and to analyze their environmental control.

Three phytoplankton production regimes were objectively identified on the $P-B$ diagram for the NEW and corresponded to 3 of those originally proposed by Legendre \& Le Fèvre (1991; see 'Introduction'). Regime 5 , which differed most from the other 2 regimes in terms of both $B_{\mathrm{L}} / B_{\mathrm{T}}$ and $P_{\mathrm{L}} / P_{\mathrm{T}}$ (Fig. 3), also differed in the horizontal (Fig. 4) and vertical (Fig. 5) distributions of phytoplankton and in several physical and chemical characteristics in the euphotic zone (Table 1). This regime occurred in ice-covered waters where nitrate was more abundant than in Regimes 1 and 2 and average irradiance in the euphotic zone was low (ca 4 mol photons $\mathrm{m}^{-2} \mathrm{~d}^{-1}$; Table 1) due to attenuation by the ice cover. Thus, Regime 5 corresponded to a non-bloom situation, characterized by a dominance of flagellates (Table 3) and low primary production and biomass (Table 2).

The differences between Regimes 1 and $2\left(P_{\mathrm{L}} / P_{\mathrm{T}}\right.$ dominant taxa, and depth of the chl a maximum) appeared to be controlled by hydrodynamics, as shown by different depths of the surface mixed layer in the 2 regimes (Table $1, z_{m}$; Table $4 ;$ Fig. 5, $\sigma_{t}$ profiles). Regime 2 developed in well stratified and relatively ice-free waters where surface nutrients were depleted and centric diatoms build a maximum associated with the relatively deep pycnocline (Table 1; $z_{m}$ ). At the northern edge of the Norske Øer Ice Barrier, the effects of local run-off and sea ice melting were not observed (Fig. 2b; FWC $<0.25 \mathrm{~m}$ ) because a northward flow of East Greenland Shelf Water passes under the Ice Barrier and emerges to the north of it (Schneider \& Budéus 1994). Emerging waters were vertically well mixed and became progressively stratified near the surface as they mixed with the surrounding fresher waters along the Norske Trough. This hydrodynamic process, which persisted throughout the melting season, is thought to replenish nutrients in surface waters of the polynya (Fig. 2c, d) (Lara et al. 1994). Stations with Regime 1 were associated to the south of the NEW Polynya, with these hydrodynamic features.

\section{Temporal and spatial successions of the 3 regimes}

Although flagellates were dominant in the nonbloom situation (Table 3 ), the range of their abundances in the 3 regimes were similar (100 to $2200 \times 10^{6}$ cells $\mathrm{m}^{-3}$ ). Legendre \& Rassoulzadegan (1995) qualified this situation of 'year-round conveyor belt', linking successive blooms. In Arctic waters, the seasonal succession generally begins with flagellates, which are followed by pennate diatoms, these being progressively replaced by centric diatoms (Guillard \& Kilham 1977, Gradinger \& Baumann 1991). On the basis of the taxonomic dominance in the 3 regimes, we suggest the following succession pattern for the NEW. There, the non-bloom situation (Regime 5) develops into Regime 1 , which in turn evolves into Regime 2. The development from Regimes 5 to 1 is likely triggered by increasing average irradiance in the euphotic zone (Table 4), which corresponds to the local opening of the NEW Polynya (Table 1; $\Phi$ ). A large fraction of the pennate diatoms, which dominate Regime 1, may be released from melting ice flows (Michel et al. 1993).

The depletion of surface nutrients and deepening of the surface mixed layer, which was probably responsible for initiating the succession from Regime 1 to Regime 2 (Table 4), did not take place in the tongue of emerging waters north of the Norske Øer Ice Barrier. In that area, Regime 1 was maintained over the whole sampling season. Due to the clockwise surface circulation along the system of troughs, phytoplankton production was probably advected from the tongue of emerging waters toward the Westwind Trough, which would explain the presence of Regime 1 phytoplankton in an area where surface nutrients were low and the mixed layer was relatively deep. In the northern part of the NEW Polynya, Regime 1 was never observed, which suggests that the onset of the spring bloom occurred there prior to 23 May. In Regime 2, given that centric diatoms are generally buoyant (Smayda 1970, Bienfang et al. 1982), these could accumulate in the pycnocline where large phytoplankton accounted for most of the biomass (Fig. 5), whereas the surface waters were dominated by intermediate values of $B_{\mathrm{L}} / B_{\Upsilon}$ which generally characterized Regime 3 (Fig. 3). Thus, it is expected that, as large phytoplankton sink out of the surface layer, i.e. as the mixed layer deepens, the succession of production regimes in the NEW Polynya would further develop from Regime 2 to Regime 3, before coming back to Regime 5 when the NEW Polynya closes in early autumn 


\section{The fate of production in the 3 regimes}

The export of phytoplankton production from the euphotic zone includes the grazing, downward flux, and advection of intact and repackaged phytoplankton. Sinking and grazing are size-differential mechanisms, so that the 3 regimes are expected to differ in the fate of their biogenic carbon.

According to the model of Tremblay \& Legendre (1994), the position of each station in the $P$ - $B$ diagram, relative to the main diagonal (where $P_{\mathrm{L}} / P_{\mathrm{T}}=B_{\mathrm{L}} / B_{\uparrow}$ ), reflects the balance between production and standing stock for the small and large phytoplankton. These authors showed that: along the diagonal, the contribution of large phytoplankton to total export is balanced by their contribution to total production; position above the diagonal indicates that the contribution of large phytoplankton to total export exceeds their contribution to total production; position below the diagonal would indicate the reverse. Conversely, position below the diagonal indicates that the contribution of small phytoplankton to total export exceeds their contribution to total production, whereas position above the diagonal indicate the reverse. In the $P-B$ diagram for the NEW (Fig. 3), stations corresponding to Regimes 2 and 5 were generally located below the diagonal. Thus, in these 2 regimes, large phytoplankton would tend to accumulate and/or small cells would tend to be preferentially exported. Stations in Regime 1 were distributed above and below the diagonal, indicating that large phytoplankton would be preferentially exported at some stations and tend to accumulate at others. From arguments in Tremblay \& Legendre (1994), it is concluded that Regime 1 stations below the diagonal should correspond to the first phase of blooms (i.e. accumulation of biomass faster than export), whereas stations above the diagonal should correspond to later phases (i.e. increased export of biomass). All Regime 1 stations sampled along the Norske Trough were located below the diagonal, which suggests first-phase blooms there. Later phases of Regime 1 (i.e. stations above the diagonal) were sampled in the Westwind Trough. This indicates that large phytopiankton no longer accumulated as they were advected along the Westwind Trough, toward nutrient depleted and deeply stratified waters.

Accumulation of large phytoplankton at stations located along the Norske Trough does not imply that export there was low. In fact, potential sedimentation rates there were high ( 116 to $327 \mathrm{mg} \mathrm{C} \mathrm{m}^{-2} \mathrm{~d}^{-1}$ ) and chl a concentrations, $10 \mathrm{~m}$ above the seafloor, were sometimes comparable to surface values (>1 $\mathrm{mg} \mathrm{chl} \mathrm{a} \mathrm{m}^{-3}$; Legendre et al. 1994). Position above the main diagonal simply means that the proportion of total export effected by large phytoplankton is potentially not as high as their share of the total production. The model of Legendre \& Le Fèvre (1991) predicts an increase in the ratio of export to production, from Regimes 5 to 1 In agreement with the model, phytoplankton assemblages (dominated by small cells) in Regime 5 had lower potential sedimentation (ca $20 \%$ of $P_{\mathrm{T}}$ ) than that (dominated by large cells) in Regime 1 (ca $46 \%$ of $P_{\Upsilon}$ ). A possible explanation for the observed lower value in the ratio of export to production in Regime 2 (ca $15 \%$ of $P_{T}$ ) is the high buoyancy of centric diatoms (Smayda 1970, Bienfangetal. 1982) which dominated in Regime 2. It is expected that, in the NEW, 2 strong pulses of sedimentation should take place, i.e. a first one corresponding to early surface stratification and increased daily irradiance (Regime 1) and a second in early autumn upon breakdown of surface stratification (Regime 3) and release of large phytoplankton accumulated at the bottom of the euphotic zone during summer Regime 2. This is in agreement with the annual pattern of sedimentation recorded in the NEW from August 1992 to July 1993, from moored time series sediment traps (Bauerfeind et al. 1996).

Bolms (1986) found large numbers of zooplankton. eggs and nauplii in the NEW Polynya compared to the ice-covered waters of the East Greenland Current. If the reproduction of copepods was triggered by the phytoplankton bloom (Regime 1), then grazing pressure would be higher in Regime 2 compared to Regimes 1 and 5 because Regime 2 follows Regime 1 in the seasonal succession. This idea is supported by the fact that, in June 1991 (Hirche et al. 1994) and May to July 1993 (J. Michaud, L. Fortier, S. Pesant \& H. J Hirche unpubl.), the number of eggs per female of large copepods (Calanus finmarchicus, C. glacialis and C. hyperboreus) was higher at stations belonging to Regime 2 (i.e. on the Ob Bank and at the western edge of Belgica bank) compared to those belonging to Regimes 1 and 5. These species of copepods have been documented to graze on Phaeocystis (Estep 1990, Hansen et al. 1990) and on centric diatoms (Turner 1984), whose highest abundances were at Regime 2 stations (Table 3). This suggests that herbivory could be an important pathway of the food web in Regime 2

However, in Regime 2, the position of stations in the $P$ - $B$ diagram below the main diagonal (Fig. 3 ) suggests that large phytoplankton accumulated faster there than they were grazed. Selective predation by copepods on ciliates (Hansen et al. 1993) could be an alternative to the herbivorous pathway mentioned above. There is some evidence that large and small copepods prefer microzooplankton to phytoplankton (Stoecker \& Capuzzo 1990) and that egg production of copepods (experiments on genus Acartia) feeding on ciliates is significantly higher than that of copepods feeding on phytoplankton (Stoecker \& Egloff 1987, White \& Roman 1992). Thus, assuming that ciliates grazed on 
bacteria, the microbial pathway could also be important to the food web in Regime 2.

\section{Overall ecological significance}

Based on literature (see 'Introduction'), we hypothesized that the presence of open waters, mixed ice cover and ice-covered conditions in the NEW should favor the development of phytoplankton production Regimes 3, 1 , and 5, respectively. The mixed ice cover and ice-covered waters found in the NEW indeed corresponded to Regimes 1 and 5. However, none of the stations sampled in the NEW exhibited $B_{\mathrm{L}} / B_{\mathrm{T}}$ and $P_{\mathrm{L}} / P_{\mathrm{T}}$ characteristics of production Regime 3 , i.e. production and biomass equally shared by the 2 size fractions. Instead, the open waters favored the development of Regime 2 . which differs from Regime 3 in its $B_{\mathrm{L}} / B_{\mathrm{T}}$ characteristics, i.e. biomass in Regime 2 is dominated by large phytoplankton. However, it is expected that, as the mixed layer deepens and the average irradiance in the pycnocline lowers, large phytoplankton would sink out of the surface layer and the succession of production regimes in the NEW Polynya would further develop from Regime 2 to Regime 3 . This suggests that the relationship between the depths of the surface mixed layer and of the euphotic zone may be critical in determining production Regime $2\left(z_{\mathrm{m}} / \mathrm{z}_{\mathrm{eu}}<1\right)$ vs Regime $3\left(z_{\mathrm{m}} / \mathrm{z}_{\mathrm{eu}} \geq 1\right)$.

Legendre \& Rassoulzadegan (1995) proposed that different food webs develop under the influence of hydrodynamics and the size structure of phytoplankton (see also Kiørboe 1993). In the NEW, hydrodynamics (e.g. emerging waters, advection, and mixing) and the ice cover likely determined the irradiance and/or nutrient availability (Figs. 2 \& 3; see also Lara et al. 1994), hence the intensity and size structure of primary production (bottom-up control; Cushing 1989, Legendre 1990). The size structure of phytoplankton biomass compared to that of primary production $\left(B_{\mathrm{L}} / B_{\mathrm{T}} \mathrm{vs}\right.$ $P_{\mathrm{L}} / P_{\mathrm{T}}$ ) reflects, in turn, the intensity of export (topdown control; Tremblay \& Legendre 1994). It follows that the different primary production regimes not only reflect different export characteristics, as proposed by Tremblay \& Legendre (1994), but also could correspond to different pathways of the food web.

Acknowledgements. This research was funded by a Collaborative Special Project grant from the Natural Sciences and Engineering Research Council of Canada (NSERC) and by grants to L.L., M.G., and R.E.H.S. from NSERC and to GIROQ (Groupe interuniversitaire de recherches océanographiques du Québec) from NSERC and the Fonds FCAR of Québec This is contribution no. 1088 of the Alfred Wegener Institute for Polar and Marine Research and is a contribution to the research programme of GIROQ. We thank the master and crew of the RV 'Polarstern', G. Bergeron, P. K. Bjørnsen, K. Daly, C. Fraiken, C. Hellum. B. Leblanc, S. Lessard, F. McGui- ness, and T G. Nielsen for assistance in the fıeld, C. Belzile and M.J. Lavoie for assistance with the laboratory analyses and data analyses. We thank also G. Budéus, C. Garnty, and W. Schneider who provided the physical data and provided helplul suggestions durng the field work.

\section{LITERATURE CITED}

Bauerfeind E, Garrity C, Krumbholz M, Ramseier RO, Voß M (1996) Seasonal variability of sediment trap collections in the Northeast Water Polynya. Part 2: Biochemical and microscopic composition of sedimenting matter J Mar Syst (in press)

Baumann MEM (1987) Phytoplankton and zooplankton relationship on the East Greenland Shelf in July and August 1985. ICES 1987 Symp Paper 10

Berg H. Purcell EM (1977) Physics of chemoreception. Biophys J 20:193-219

Bienfang PK (1981) SETCOL - a technologically simple and reliable method for measuring phytoplankton sinking rates. Can J Fish Aquat Sci 38:1289-1294

Bientang PK, Harrison PJ, Quarmby LM (1982) Sinking rate response to depletion of nitrate, phosphate and silicate in four marine diatoms. Mar Biol 67:295-302

Bjornsen PK (1988) Phytoplankton release of organic matter: why do healthy cells do it? Limnol Oceanogr 33:151-154

Bolms G (1986) Zur Verteilung des Mikrozooplanktons in der Framstraße zwischen Gronland und Spitzbergen. MSc thesis, University of Kiel

Budéus G. Schneider W, Brunben J, Damm M, Plugge R (1994) Ship-borne physical oceanography. Ber Polarforsch 142:16-105

Cushing DH (1989) A difference in structure between ecosystems in strongly stratified waters and in those that are only weakly stratified. J Plankton Res 11:1-13

Diel S, Buma AGJ (1989) Phytoplankton and zooplankton relationship on the East Greenland Shelf in July and August 1985. Rapp PV Réun Cons Int Explor Mer 188 172

Estep KW (1990) Predation by copepods upon natural populations of Phaeocystss pouchetii as a function of the physiological state of the prey. Mar Ecol Prog Ser 67:235-249

Fortier L, Le Fèvre J, Legendre L (1994) Export of blogenic carbon to fish and to the deep ocean: the role of large planktonic microphages. J Plankton Res 16:809-839

Garrity C, Ramseier R (1994) Remote sensing of ice in the Northeast Water Polynya. In: Fortier L, Robineau B (eds) A second Canadian progress report (NEW Project). GIROQ. Université Laval, Québec, p 13-19

Gradinger R, Baumann MEM (1991) Distribution of phytoplankton communities in relation to the large-scale hydrographical regume in the Fram Strait Mar Biol 111:311-321

Guillard RRL, Kilham P (1977) The ecology of marine planktonic diatoms. In: Werner $D$ (ed) The biology of diatoms Blackwell Scientific Publications, Oxford, p 372-469

Hansen FC, Reckermann M, Klein Breteler WCM, Riegman R (1993) Phaeocystus blooming enhanced by copepod predation on protozoa: evidence from incubation experiments Mar Ecol Prog Ser 102:51-57

Hansen FC, Tande KS, Berggreen UC (1990) On the trophic fate of Phaeocystis pouchetir (Hariot). III. Functional responses in grazing demonstrated on juvenile stages of Calanus finmarchicus (Copepoda) fed diatoms and Phaeocystis. J Plankton Res 12:1173-1187

Hirche HJ, Baumann MEM, Kattner G, Gradinger R (1991) Plankton distribution and the impact of copepod grazing 
on primary production in Fram Strait, Greenland Sea. $J$ Mar Syst 2:477-494

Hirche HJ, Hagen W, Mumm N, Richter C (1994) The Northeast Water Polynya, Greenland Sea. IIl. Meso- and macrozooplankton distribution and production of dominant herbivorous copepods during spring. Polar Biol 14: 491-503

Kattner G, Budéus G (1996) Nutrient status of the Northeast Water Polynya. J Mar Syst (in press)

Kattner G. Hollmann B, Michel. A, Richter KU, StürckenRodewald M (1994) Distribution of nutrients. Ber Polarforsch $142: 106-188$

Kiørboe T (1993) Turbulence, phytoplankton cell size, and the structure of pelagic food webs. Adv Mar Biol 29:1-72

Kirk JTO (1983) Light and photosynthesis in aquatic ecosystems. Cambridge Univ Press, Cambridge

Lance GN, Williams WT (1966) A generalized sorting strategy for computer classifications. Nature 212:218

Lance GN, Williams WT (1967) A general theory of classificatory sorting strategies. I. Hierarchical systems. Comp J 9 $373-380$

Lara RJ, Kattner G, Tillman U, Hirche HJ (1994) The Northeast Water Polynya (Greenland Sea). II. Mechanisms of nutrient supply and influence on phytoplankton distribution. Polar Biol 14:483-490

Legendre L (1990) The significance of microalgal blooms for fisheries and for the export of particulate organic carbon in oceans. J Plankton Res 12:681-699

Legendre L, Gosselin M, Hirche HJ, Kattner G, Rosenberg G (1993) Environmental control and potential fate of sizefractionated phytoplankton production in the Greenland Sea $\left(75^{\circ}\right.$ N). Mar Ecol Prog Ser 98:297-313

Legendre L, Le Fèvre J (1991) From individual plankton cells to pelagic ecosystems and to global biogeochemical cycles. In: Demers $S$ (ed) Particle analysis in oceanography. Springer-Verlag, Berlin, p 261-300

Legendre L, Legendre P (1983) Numerical ecology. Elsevier, Amsterdam

Legendre L, Pesant S, Robineau B (1994) Development and fate of phytoplankton in the Northeast Water Polynya. In: Fortier L, Robineau B (eds) A second Canadian progress report (NEW Project). GIROQ, Université Laval, p $31-36$

Legendre L, Rassoulzadegan F (199.5) Plankton and nutrient dynamics in marine waters. Ophelia 41:153-172

Legendre P, Vaudor A (1991) Le progiciel R-analyse mult1dimensionnelle, analyse spatiale. Département de sciences biologiques. Université de Montréal

Logan BE (1993) Theoretical analysis of size distributions determined with screens and filters. Limnol Oceanogr 38 : $372-381$

Logan BE (1994) Variable retention of dıatoms on screens during size separation. Limnol Oceanogr 39:390-395

Lund JWG, Kipling C, Le Cren ED (1958) The inverted microscope method of estimating algal numbers and the statist1cal basis of estimations by counting. Hydrobiologia 11: $143-170$

Malone TC, Chervin MB, Boardman DC (1979) Effects of 22$\mu \mathrm{m}$ screens on size-frequency distributions of suspended particles and biomass estimates of phytoplankton size fractions. Limnol Oceanogr 24:956-960

Medlin LK, Priddle J (1990) Polar marine diatoms. British Antarctic Survey, Cambridge

Michel C, Legendre L, Therrault JC, Demers S, Vandevelde T (1993) Springtime coupling between ire algal and phytoplankton assemblages in southeastern Hudson Bay, Canadian Arctic. Polar Biol 13:441-449
Morel A, Bricaud A (1981) Theoretical results concerning light absorption in a discrete medium, and application to specific absorption of phytoplankton. Deep Sea Res 28: $1375-1393$

Parsons TR, Maita Y, Lalli CM (1984) A manual of chemical and biological methods for seawater analysis. Pergamon Press, Toronto

Ramseier RO, Bauerfeind E, Garity C, Walsh ID (1996) Seasonal variability of sediment trap collections in the Northeast Water Polynya. Part 1: Sea-ice parameters and partıcle flux. J Mar Syst (in press)

Robineau B, Legendre L, Therriault JC, Fortier L, Rosenberg $G$. Demers S (1994) Ultra-algae $(<5 \mu \mathrm{m})$ in the ice, at the ice-water interface and in the under-ice water column (southeastern Hudson Bay, Canada). Mar Ecol Prog Ser 115:169-180

Schandelmeier L, Alexander V (1981) An analysis of the influence of ice on spring phytoplankton population structure in the southeast Bering Sea. Limnol Oceanogr 26:935-943

Schlotzhauer SD, Littell RC (1987) SAS system for elementary statistical analysis. SAS Institute Inc, Cary, NC

Schneider W, Budéus G (1994) The Northeast Water Polynya (Greenland Sea). I. A physical concept of its generation. Polar Biol 14:1-9

Sherr EB, Sherr BF (1994) Bacterivory and herbivory: key roles of phagotrophic protists in pelagic food webs. Microb Ecol 28:223-235

Smayda TJ (1970) The suspension and sinking of phytoplankton in the sea. Oceanogr Mar Biol Ann Rev 8:353-414

Smith WO Jr (1995) Primary productivity and new production in the Northeast Water (Greenland) Polynya during summer 1992. J Geophys Res 100:4357-4370

Smith WO Jr, Baumann MEM, Wilson DL, Aletsee L (1987) Phytoplankton biomass and productivity in the marginal ice zone of the Fram Strait during summer 1984. J Geophys Res 92:6777-6786

Smith WO Jr, Brightman RI (1991) Phytoplankton biomass and photosynthetic response during the winter-spring transition in the Fram Strait. J Geophys Res 96:4549-4554

Smith WO Jr, Walsh ID, Booth BC, Deming JW (1995) Particulate matter and phytoplankton and bacterial biomass distributions in the Northeast Water Polynya during summer 1992. J Geophys Res 100:4341-4356

Stoecker DK, Capuzzo JM (1990) Predation on protozoa: its importance to zooplankton. J Plankton Res 12:891-908

Stoecker DK, Egloff DA (1987) Predation by Acartia tonsa Dana on planktonic ciliates and rotifers. J Exp Mar Biol Ecol 110:53-68

Tremblay JE, Legendre L (1994) A model for the size-fractionated biomass and production of marine phytoplankton. Limnol Oceanogr 39:2004-2014

Turner JT (1984) The feeding ecology of some zooplankters that are important prey items of larval fish. NOAA Tech Rep NMFS, Washington, DC, 7:1-28

Vincent WF, Roy S (1.993) Solar ultraviolet-B radiation and aquatic primary production: damage, protection, and recovery. Environ Rev 1:1-12

White JR, Roman MR (1992) Egg production by the calanoid copepod Acartia tonsa in the mesohaline Chesapeake Bay: the importance of food resources and temperature Mar Ecol Prog Ser 86:238-249

Yager PL, Wallace DWR, Johnson KM, Smith WO Jr, Minnett PJ, Deming JW (1995) The Northeast Water Polynya as an atmospheric $\mathrm{CO}_{2}$ sink: a seasonal rectification hypothesis J Geophys Res 100:4389-4398

Zar JH (1984) Biostatistıcal analysıs. Prentice Hall, Englewood Cliffs, NJ

Manuscript first recejved: October 6, 1995

Revised version accepted: June 25, 19.96 